\begin{tabular}{|c|l|}
\hline Title & $\begin{array}{l}\text { Prevention of renal damage and decrease of urinary kinins excretion by chronic treatments with } \\
\text { enalapril and captopril in stroke-prone spontaneously hypertensive rats }\end{array}$ \\
\hline Sub Title & \\
\hline Author & $\begin{array}{l}\text { 川島, 紘一郎(Kawashima, Koichiro) } \\
\text { 渡辺, 卓司(Watanabe, Takushi) } \\
\text { 曽我部, 博文(Sokabe, Hirofumi) } \\
\text { 斎藤, 建(Saito, Ken) }\end{array}$ \\
\hline Publisher & 共立薬科大学 \\
\hline Publication year & 1987 \\
\hline Jtitle & $\begin{array}{l}\text { 共立薬科大学研究年報 (The annual report of the Kyoritsu College of } \\
\text { Pharmacy). No.32 (1987.),p.70- 70 }\end{array}$ \\
\hline JaLC DOI & \\
\hline Abstract & \\
\hline Notes & 抄録 \\
\hline Genre & Technical Report \\
\hline URL & https://koara.lib.keio.ac.jp/xoonips/modules/xoonips/detail.php?koara_id=AN00062898-0000003 \\
2-0070
\end{tabular}

慶應義塾大学学術情報リポジトリ(KOARA)に掲載されているコンテンツの著作権は、それぞれの著作者、学会または出版社/発行者に帰属し、その権利は著作権法によって 保護されています。引用にあたっては、著作権法を遵守してご利用ください。

The copyrights of content available on the KeiO Associated Repository of Academic resources (KOARA) belong to the respective authors, academic societies, or publishers/issuers, and these rights are protected by the Japanese Copyright Act. When quoting the content, please follow the Japanese copyright act. 


\title{
Prevention of Renal Damage and Decrease of Urinary Kinins Excretion by Chronic Treatments with Enalapril and Captopril in Stroke- prone Spontaneously Hypertensive Rats
}

\author{
Koichiro Kawashima, Takushi X. Watanabe*, \\ Hirofumi SoKABE* and Ken SAITo** \\ 川島紘一郎, 渡辺卓司*, 曾我部博文*, 斎藤 建**
}

Chronic treatments with enalapril and captopril produced significant reductions of blood pressure and $\mathrm{U}_{\mathrm{KIN}} \mathrm{V}$, and prevented renal damage in adult SHRSP rats. $\mathrm{U}_{\mathrm{KIN}} \mathrm{V}$ tended to decrease soon after the beginning of the treatment and was significantly decreased during the chronic treatment with CEI. These results are consistent with the previous study. Thus, these data do not support the hypothesis of possible additional involvement of renal kinins in the antihypertensive effect of CEI. In the SHRSP with activated RA system, enalapril and captopril appear to produce antihypertensive effect through reduction of ANG II formation. A good positive correlation between $\mathrm{UV}$ and $\mathrm{U}_{\mathrm{KIN}} \mathrm{V}$ suggest that renal kinins are washed out from the tubules by urine flow.

A good positive correlation between MBP and renal damage indicates that CEI prevented renal damage through the reduction of blood pressure and ANG II formation. Furthermore, a positive correlation between UV and MBP suggests that pressure diuresis may be involved in the increased UV found in the control group.

本報告は Clin. Exp. Hyper., A 9, 409-413（1987）に発表.

* 自治医科大学薬理学教室

** 自治医科大学病理学教室 